slightly pleomorphic mast cells, which made up $5 \%$ of all nucleated cells. However, focal mast cell infiltration was not found histologically, and malignant mastocytosis was thought unlikely. This reactive increase in mast cells was probably caused by the application of a particular haemopoietic growth factor (G-CSF) which would also strongly suggest a very close relation between mast cells and the myelomonocytic system.

1 Bolz S, Ruck P, Schaumburg-Lever G, Horny H-P, Radzun H-J, Kaiserling E. Use of monoclonal antibodies KP1 (CD68) and KiM1p for identification of cells of the mononuclear phagocyte system: immunohistological and phagocyte system: immunohistological and immunoelectronmicroscopic findings (

2 Ruck P, Horny H-P, Kaiserling E. Immunoreactivity of human tissue mast cells: nonspecific binding of primary antibodie against regulatory peptides by ionic linkage. J Histochem Cytochem 1990;38:859-67.

3 Horny H-P, Ruck M, Wehrmann M, Kaiserling E. Blood findings in generalized mastocytosis: evidence of frequent simultaneous occurrence of myeloproliferative disorders. $\mathrm{Br} J$ Haematol 1990;76:186-93.

4 Kirshenbaum AS, Kessler SW, Goff JP, Metcalfe DD. Demonstration of the origin of human mast cells from CD $34+$ bone marrow human mast cells from CD34 + bone marrow
progenitor cells. J Immunol 1991;146: progenitor

\section{HPV genotypes in cervical neoplasia in South Africa}

Our recent publication on the prevalence of human papillomavirus (HPV) DNA in cervical intraepithelial neoplasm (CIN) using non-isotopic in situ hybridisation (NISH) in archival biopsy material from South Africa stated that there were no previously published data from that country. ${ }^{1}$ We have now become aware of a study from Cape Town on the prevalence of HPV DNA in CIN 3 using Southern analysis for HPV types $6,11,16,18$, 31,33 and $35 .^{2}$ There are several similarities in these independent studies using different molecular techniques (but the same probes) in patients from South Africa. Comparing our CIN 3 group from Durban with that from Cape Town, it is evident that there is a low prevalence of HPV 16 in Durban 15/55 (27\%) and Cape Town 16/98 (16\%) compared with Oxford patients $24 / 49$ (49\%). Furthermore, none of these groups showed any evidence of HPV 6, 11, or 31 in CIN cases. Excluding the unclassified group in Williamson's series, ${ }^{2}$ the prevalence of HPV 16,18, and 31 in CIN 3 is less than $50 \%$ in Durban and Cape Town. The unclassified HPVs in the Cape Town series $(36 \%)$, along with $59 \%$ of the Durban biopsy specimens of CIN 3 (with morphological evidence of wart virus infection) that did not contain HPV DNA by NISH, $^{1}$ confirms our suspicion of a high prevalence of minor or unclassified HPV types in South Africa.

K COOPER JO'D MCGEE University of Oxford, Nuffield Department of athology and Bacteriology, Radcliffe Hospital,
Oxford $O X 39 D U$

1 Cooper K, Herrington CS, Graham AK, Evans MF, McGee JO'D. In situ HPV genotyping of cervical intraepithelial neoplasia in South Africa and British patients: Evidence for
putative HPV integration. J Clin Pathol putative HPV

2 Williamson A-L, Dehaeck CMC, Soeters R. Typing of human papillomavirus in cervical intraepithelial neoplasia grade 3 biopsies from Cape Town. J Med Virol 1989;28:146-9.
Reconstruction of fetuses after dissection

The paper by Gau, Napier, and Bhundia describes the use of the tissue adhesive Histoacryl Blue for the reconstruction of fetuses after dissection. ${ }^{1}$ In Huntingdon we use a similar technique, but with ordinary Superglue (cyanoacrylate), which produces a very acceptable cosmetic result. Superglue is also very useful for closing small lacerations, particularly on the face or hands, which may be present in deaths associated with trauma, and also accidental cuts on visible areas of the neck which may occasionally occur in the course of necropsy. Persistent leakage of blood and fluid after removal of the calf muscles has also been remedied by running a line of superglue over the sutures.

The use of Superglue in this way is by no means new, in fact it is used by some anatomy departments to repair small nerves and vessels on demonstration specimens, which sometimes become severed by heavy handed prosectors or enthusiastic students. Superglue can be used by pathologists to reconstruct organs after dissection, for use as teaching specimens or "pots". I understand that some undertakers even use Superglue on the eyelids of cadavers if they will not stay closed.

Although not subjected to such a rigorous study as that by Gau et al, in my experience ordinary Superglue produces good tissue adhesion, as anyone who has ever stuck their fingers together while attempting to repair some household ornament, or child's toy, will testify. The glue line has a slightly firmer consistency than the adjacent tissue, but the glue is colourless. Any excess dries to a crust, presumably the coagulum described in Gau's paper, most of which can be removed with forceps or a scalpel blade. Superglue is much cheaper and more readily available than the specialised surgical adhesive described. MD HARRIS

Department of Histopathology, Hinchingbrooke Hospital,

Huntingdon,
Cambridgeshire PE18 8NT

1 Gau GS, Napier K, Bhundia J. Use of a tissue adhesive to repair fetal bodies after dissection. $J$ Clin Pathol 1991;44:759-60.

\section{Dr Gau comments:}

We were interested to note Dr Harris's comments on our paper and would like to indicate that we realise that many people have used modern "over the counter" superglues in their pathological practice. The reason we avoided this type of Superglue was the warning on the packaging that this glue should not be used where there is "wet service". As it was essential that these repairs remained aesthetic for many weeks we felt it unwise to use such glue.

On the question of cost, we would like to point out that all accident and emergency departments in this country now use Histoacryl Blue for the repair of lacerations. Generally little of the total glue is used and, as the open capsule is no longer deemed sterile, the remnant is frequently discarded. We feel sure that an encouraging word to sister-incharge would easily ensure an ample supply of opened "unsterile" Histoacryl Blue at no cost to the pathology department. This must undercut even the cheapest of superglues.

\section{Skin adnexal tumours}

I must congratulate Dr Cotton on his paper which attempts to clear the minefield of skin adnexal tumours. ${ }^{1}$ In my experience these benign lesions cause great problems with classification, often requiring serious "bench testing" and much thumbing of Lever.

Two points concern me. Dr Cotton states that "distant metastases have not been reported" for malignant pilomatricomas. Two case reports of histologically confirmed metastatic pilomatrix carcinoma do exist: Gould et al and Mir et $a l^{3}{ }^{3}$ both using the criteria of Lopransri and Mihm for diagnosis. ${ }^{4}$

He also states that Merkel cell carcinoma stains "with Cam 5.2 which oat cells do not". The product information sheet for Cam 5.2 contradicts this as both tumours can stain with Cam 5.2, usually with a paranuclear "dot" positivity. artment of Histopathology, Bury General Hospital, Lancashiroad, Bury,

1 Cotton D. Troublesome tumours 1: Adnexal tumours of the skin. J Clin Pathol tumours of

2 Gould E, Kurzon R, Kowalczyk AP, Saldana M. Pilomatrix carcinoma with pulmonary metastasis. Cancer 1984;54:370-2.

3 Mir R, Cortes E, Panagiotis A, et al. Metastatic trichomatrical carcinoma. Arch Pathol Lab Med 1986;110:660-3

4 Lopransri S, Mihm MC. Pilomatrix carcinoma or calcifying epitheliocarcinoma of malherbe. or calcifying epitheliocarcinc

5 Rosai J. Ackerman's Surgical Pathology. Seventh Edition. New York: CV Mosby Company, 1989.

\section{Dr Cotton comments:}

I thank Dr Cross for his helpful comments. I have looked up the references to metastasis in malignant pilomatrixomas (or pilomatrical carcinomas) and there are about six cases that I can locate. My comment about metastasis not being reported referred to aggressive variants of pilomatrixomas rather than the frank carcinomas with pilomatrix differentiation. In the case reports that I have read some were frank squamous carcinomas with pilomatrical areas, some were carcinoma arising in pilomatrixoma, and two were possibly metastases arising from the cellular aggressive variants of pilomatrixoma. Dr Cross is, of course, right to comment that there are reports of malignant pilomatrixomas that have metastasised. I am still reluctant to believe that even cellular aggressive variants do so, although I agree that frank carcinomas do.

As to Dr Cross's comments regarding cytokeratin staining of Merkel cell versus oat cell tumours, there is some conflicting evidence. Dr Rosai in Ackerman's Surgical Pathology refers only to keratin stains and does not mention CAM 5.2 as far as I can see. The reference that he quotes refers to a series of cytokeratin antibodies raised in the author's own laboratories and which are not directly comparable with CAM 5.2 as far as I can ascertain. On the whole, the typical "ball in a fist" cytoplasmic dot positivity for CAM 5.2 is highly characteristic of Merkel cell tumours in my experience, and positivity in oat cell carcinomas is much less frequent and more diffuse when it occurs. 